BUDGETING : Journal of Business, Management and Accounting Volume 2, Nomor 1, Desember 2020

e-ISSN: 2715-2480

p-ISSN: $2715-1913$

DOI : https://doi.org/10.31539/budgeting.v2i1.1224

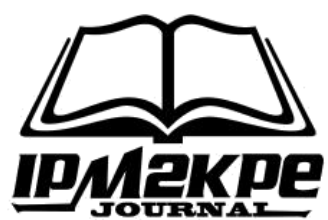

\title{
PENENTUAN BIAYA STRATEGIS MELALUI ANALISIS VALUE CHAIN
}

\author{
Achmad Arifin ${ }^{1}$, Moh. Halim ${ }^{2}$, Astrid Maharani ${ }^{3}$ \\ Universitas Muhammadiyah Jember ${ }^{1,2,3}$ \\ arifahmad6696@gmail.com ${ }^{1}$
}

\begin{abstract}
ABSTRAK
Tujuan dari penelitian ini adalah untuk menentukan biaya strategis dengan menggunakan analisis rantai nilai pada CV. Karunia Jaya. Metode yang digunakan dalam penelitian ini adalah metode deskriptif yang dilakukan dengan mendeskripsikan temuan-temuan yang diperoleh dari data yang dikumpulkan melalui proses observasi, wawancara dan dokumentasi pada objek penelitian. Hasil penelitian menunjukkan bahwa dalam menentukan biaya strategis perusahaan tidak melihat biaya strategis melalui analisis rantai nilai yang mengakibatkan ketidaktahuan manajer bahwa biaya yang dikeluarkan semakin meningkat. Simpulan, CV. Karunia Jaya perlu menggunakan analisis rantai nilai dengan melacak biaya untuk aktivitas yang membentuk nilai dan menetapkan biaya untuk aktivitas tersebut.
\end{abstract}

Kata Kunci: Analisis Rantai Nilai, Biaya Strategis, Laporan Keuangan, UMKM

\section{ABSTRACT}

The purpose of this study was to determine strategic costs using value chain analysis at $C V$. Karunia Jaya. The method used in this research is descriptive method which is done by describing the findings obtained from the data collected through the process of observation, interviews and documentation on the research object. The results showed that in determining strategic costs the company did not look at strategic costs through value chain analysis which resulted in managers' ignorance that the costs incurred were increasing. In conclusion, CV. Karunia Jaya needs to use value chain analysis by tracking costs for activities that create value and assigning costs to those activities.

Keywords: Value Chain Analysis, Strategic Costs, Financial Statements, UMKM

\section{PENDAHULUAN}

Persaingan perusahaan-perusahaan pada era milenial semakin meningkat. Dunia bisnis semakin cepat berkembang dengan menggunakan strategi dari masing-masing perusahaan. Perusahaan juga terus memaksimalkan kemampuannya dalam menghadapi persaingan dengan perusahaan lain. Produsen terus mencari ide untuk memberikan citra yang baik dan unggul bagi produknya. Setiap konsumen mempunyai sikap dan perilaku yang berbeda-beda terhadap suatu produk yang bersangkutan. Persaingan telah meningkatkan standart kinerja dalam berbagai dimensi seperti kualitas, biaya dan saat pengenalan produk serta operasional yang lancar, sehingga manajer perusahaan perlu 
menggunakan hal baru agar dapat mempertahankan kelangsungan hidup perusahaan dengan melakukan perbaikan berkesinambungan.

Biaya merupakan hasil pengukuran dalam unit moneter suatu objek dan cost tercipta karena adanya kejadian ekonomi dalam suatu organisasi. Menurut Mulyana (2011) berpendapat bahwa strategi merupakan suatu perangkat kebijakan, prosedur dan pendekatan-pendekatan yang mengarahkan pada keberhasilan bisnis dalam jangka panjang. Biaya strategis merupakan penggunaan dari data-data biaya untuk mengembangkan dan mengidentifikasi strategi yang unggul dalam menghadapi persaingan dengan perusahaan lain.

Menurut Magretta (2014) rangkaian aktivitas yang dilakukan perusahaan untuk mendesain, memproduksi, menjual, mengirimkan dan mendukung produk-produknya disebut rantai nilai (value chain). Analisis value chain sebagai alat yang digunakan untuk memahami secara lebih baik terhadap keunggulan kompetitif untuk mengidentifikasi nilai pelanggan dapat ditingkatkan atau penurunan biaya. Analisis value chain sebagai salah satu bagian dari rantai nilai produk dalam pandangan perusahaan. Analisis value chain telah banyak dilakukan pada beberapa perusahaan dalam rangka meningkatkan efesiensi dan laba.

Usaha Mikro, Kecil dan Menengah (UMKM) merupakan suatu usaha produktif yang dimiliki oleh perorangan maupun badan usaha yang telah memenuhi kriteria sebagai usaha mikro. Salah satu usaha yang tergolong ke dalam UMKM yaitu CV. Karunia Jaya. CV. Karunia Jaya merupakan salah satu perusahaan yang memproduksi air minum dalam kemasan atau penghasil air mineral dalam kemasan (AMDK) di Indonesia, tepatnya terletak di Kabupaten Bondowoso, Jawa Timur. Produk AMDK yang diproduksi oleh perusahaan ini adalah air mineral $\mathrm{A}_{3}$ Fresh $\mathrm{O}_{2}$ dalam kemasan gelas $220 \mathrm{ml}$, botol $600 \mathrm{ml}$ dan dalam kemasan galon 19 liter.

CV. Karunia Jaya harus senantiasa menjaga kualitas produknya agar bisa memperoleh kepercayaan konsumen. Terlebih lagi apabila produk yang dihasilkan akan dikonsumsi oleh masyarakat. Suatu usaha yang memegang peranan penting dalam mengelola air minum dalam kemasan terutama bila dikaitkan dengan jumlah tenaga kerja yang mampu diserap. Usaha kecil ini, selain memiliki arti strategis bagi pembangunan juga sebagai upaya untuk memeratakan hasil-hasil pembangunan yang telah dicapai. Jumlah usaha kecil dari tahun ke tahun bertambah, bertahan dan 
mengalami krisis. Ada beberapa area ekonomi yang biasanya menjadi konsentrasi usaha kecil yang beranekaragam.

\section{KAJIAN TEORI}

\section{Pengertian Biaya}

Daljono (2011) berpendapat bahwa biaya adalah suatu pengorbanan sumber ekonomi yang diukur dalam satuan uang untuk mendapatkan barang atau jasa yang diharapkan akan memberikan keuntungan atau manfaat pada saat ini atau masa yang akan datang. Dalam akuntansi istilah biaya dipertegas dengan membedakan antara pengertian biaya (cost) dengan biaya sebagai beban (expense). Menurut Mursyidi (2010) menjelaskan bahwa biaya adalah sutau pengorbanan yang dapat mengurangi kas atau harta lainnya untuk mencapai tujuan baik yang dapat dibebankan pada saat ini maupun pada saat yang akan datang.

\section{Pengertian Strategis}

Strategis adalah penempatan misi penempatan sasaran organisasi dengan mengingat kekuatan eksternal dan internal dalam perumusan kebijakan tertentu untuk mencapai sasaran dan memastikan implementasinya secara tepat sehingga tujuan sasaran utama organisasi akan tercapai (Stainer \& Miner, 1997).

\section{Pengertian Biaya Strategis}

Menurut Mulyana (2011) biaya strategis adalah penggunaan data biaya untuk mengembangkan dan mengidentifikasi strategi yang unggul yang akan menghasilkan keunggulan bersaing yang berkelanjutan. Keunggulan bersaing adalah menciptakan nilai pelanggan yang lebih baik dengan biaya yang sama atau lebih baik dengan biaya yang lebih rendah dibandingkan pesaing. Wijaya (2012) berpendapat bahwa klasifikasi biaya sangat penting untuk membuat ikhtisar dalam data biaya.

\section{Pengertian Value Chain}

Pengertian analisis value chain adalah suatu alat strategi yang digunakan untuk memahami keunggulan kompetitif perusahaan dengan cara lebih baik, untuk mengidentifikasi di manakah nilai pelanggan dapat ditingkatkan atau di manakah biaya 
dapat diturunkan serta memahami hubungan perusahaan dengan pelanggan dengan pemasok, pelanggan dan industri bisnis yang lain (Blocher et al., 2016).

\section{Aktivitas-Aktivitas Analisis Value Chain}

Dalam perusahaan dapat di pandang sebagai sekumpulan aktivitas nilai (value chain). Aktivitas tersebut dilakukan dengan cara merancang, menghasilkan memasarakan mendistribusikan dan mendukung produknya. Menurut Porter (1994) menggambarkan value chain yang terdiri dari serangkaian aktivitas umum yang ditemukan pada level perusahaan. Aktivitas-aktivitas tersebut dikelompokkan ke dalam dua kelompok yaitu aktivitas utama (primary activity) dan aktivitas pendukung (support activity).

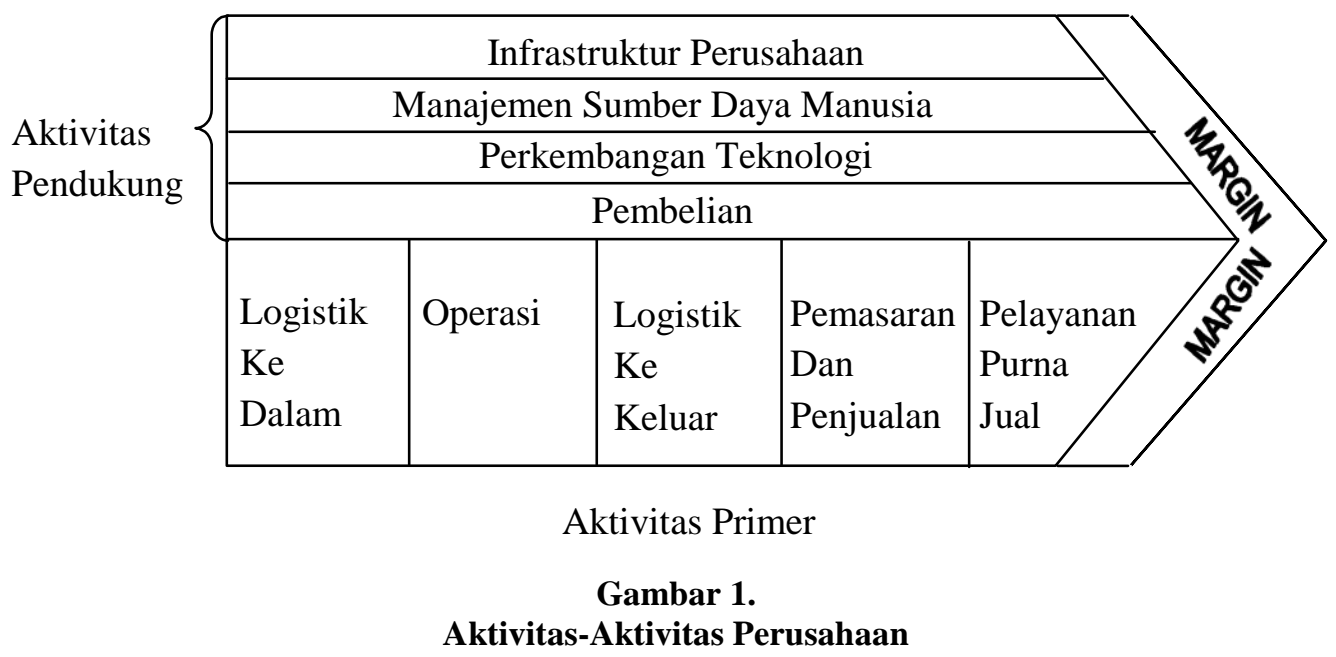

\section{Usaha Mikro, Kecil dan Menengah (UMKM)}

Beranekaragam definisi umkm di indonesia. Beberapa definisi salah satunya adalah usaha produktif yang dimiliki orang perorangan maupun badan usaha yang telah memenuhi kriteria sebagai usaha mikro. Usaha mikro, kecil dan menengah merupakan kegiatan usaha yang dapat memperluas lapangan pekerjaan dan mampu memberikan pelayanan ekonomi secara luas kepada masyarakat sekitar serta dapat berperan dalam proses pemerataan dan peningkatan pendapatan masyarakat mengangkat pertumbuhan ekonomi. Selain itu usahan kecil mikro menengah adalah salah satu pilar utama ekonomi negara yang harus memperoleh kesempatan utama, dukungan, perlindungan serta pengembangan seluas-luasnya sebagai wujud keberpihakan yang tegas kepada kelompok usahan kecil mikro menengah tanpa mengabaikan peranan usaha besar dan badan usaha milik pemerintah. 


\section{Karakteristik Usaha Mikro, Kecil dan Menengah}

Beberapa karakteristik usaha mikro, kecil dan menengah adalah: 1) jenis barang/komoditi yang diusahakan umumnya sudah tetap tidak gampang berubah; 2) lokasi/tempat usaha umumnya sudah menetap tidak berpindah-pindah; 3) pada umumnya sudah melakukan administrasi keuangan walau masih sederhana keuangan perusahaan sudah mulai dipisahkan dengan keuangan keluarga sudah membuat neraca usaha; 4) sudah memiliki izin usaha dan persyaratan legalitas lainnya termasuk NPWP; 5) sumberdaya manusia (pengusaha) memiliki pengalaman dalam berwira usaha; 6) sebagian sudah akses ke perbankan dalam hal keperluan modal; 7) sebagian besar belum dapat membuat manajemen usaha dengan baik seperti business planning.

\section{Pengertian Activity Based Costing}

Pengertian activity based costing adalah teknik manajemen untuk melakukan analisis aktivitas guna meningktakan akurasi analisis biaya dengan memperbaiki cara penelusuran biaya ke objek biaya. Teknik maanjemen dengan paradigma baru (activity based costing) didesain untuk semua jenis perusahaan, baik perusahaan manufaktur, jasa ataupun dagang. Di masa mendatang, activity based costing akan menjadi system informasi yang berpotensi besar sebagai alat pemantau rencana yang efektif karena informasinya dijadikan dasar untuk mengelola aktivitas. Menurut Witjaksono (2006) mendefinisikan activity based costing adalah sebagai suatu pengukuran biaya produk atau jasa yang didasarkan atas penjumlahan biaya dari kegiatan atau aktivitas yang timbul berkaitan dengan produksi atau jasa tersebut.

\section{Metode Activity Based Costing}

Hongren (2009) mendefinisikan activity based costing sebagai suatu sistem pendekatan perhitungan biaya yang dilakukan berdasarkan aktivitas-aktivitas yang ada di perusahaan. Sistem ini dilakukan dengan dasar pemikiran bahwa penyebab timbulnya biaya adalah aktivitas yang dilakukan dalam suatu perusahaan, sehingga wajar bila pengalokasian biaya-biaya tidak langsung dilakukan berdasarkan aktivitas tersebut. Sedangkan menurut Sujana (2006) adalah sistem menghitung setiap biaya pada masingmasing aktivitas dengan dasar alokasi yang berbeda untuk masing-masing aktivitas. 


\section{Peranan Activity Based Costing dalam Analisis Value Chain}

Analisis value chain merupakan alat analisis yang digunakan perusahaan untuk mengidentifikasi langkah-langkah spesifik yang dibutuhkan untuk menyediakan barang atau jasa yang kompetitif bagi pelanggan. Melalui peranan activity based costing perusahaan dapat mengidentifikasi aktivitas-aktivitas yang tidak sesuai dengan keinginan pelanggan atau tidak menciptakan nilai tambah. Aktivitas yang bernilai tambah jika aktivitas tersebut menghasilkan perubahan bentuk. Sedangkan perubahan tersebut tidak terjadi pada aktivitas sebelumnya dan aktivitas tersebut memungkinkan dialkuanya aktivitas yang lain.

Menurut Blocher et al., (2007) perhitungan biaya berdasarkan activity based costing (ABC) adalah pendekatan perhitungan biaya yang membebankan biaya sumber daya ke objek biaya seperti produk, jasa atau pelanggan berdasarkan aktivitas yang dilakukan untuk objek biaya tersebut. Biaya timbul hasil dari aktivitas perusahaan produk dan jasa. Activity based costing dengan membebankan biaya overhead pabrik (BOP) ke objek biaya dengan mengidentifikasi sumber daya dari aktivitas juga biaya nya serta jumlah yang dibutuhkan untuk memproduksi output.

\section{METODE PENELITIAN}

Metode yang digunakan dalam penelitian ini adalah metode deskriptif. Menurut Arikunto (2006) penelitian deskriptif adalah penelitian yang dimaksudkan untuk menyelidiki keadaan atau hal-hal lain (keadaan, kondisi, situasi, peristiwa, kegiatan) yang hasilnya dipaparkan dalam bentuk laporan penelitian. Dalam kegiatan penelitian ini, peneliti hanya memotret apa yang terjadi pada diri objek atau wilayah yang diteliti kemudian memaparkan apa yang terjadi dalam bentuk laporan penelitian secara lugas, seperti apa adanya.

Objek yang diteliti oleh peneliti adalah CV. Karunia Jaya. Objek ini merupakan perusahaan yang bergerak di bidang penindustrian dan perdagangan. Lokasi penelitian Jl. Letnan Rantam No.78, Tegalbatu Utara, Badean, Kec. Bondowoso, Kabupaten Bondowoso, Jawa Timur. Dalam penelitian ini jenis data dibagi menjadi dua, yaitu data dan primer data sekunder. Data Primer merupakan data yang dapat diperoleh langsung dari lapangan atau tempat penelitian. Data primer dimana data yang diperoleh melalui wawancara dengan pimpinan CV. Karunia Jaya. Adapun data sekunder merupakan data 
yang dapat diperoleh melalui dokumen-dokumen seperti buku, jurnal dan mengakses data internal CV. Karunia Jaya yang berupa laporan keuangan perusahan serta sumber lain yang mendukung penelitian ini.

Langkah-langkah yang dilakukan untuk menganalisis data dalam penelitian ini terdiri dari mengumpulkan data dengan melakukan observasi, wawancara serta dokumentasi, mengidentifikasi biaya strategis melalui analisis value chain pada $\mathrm{CV}$. Karunia Jaya, mendeskripsikan laporan keuangan CV. Karunia Jaya dalam tiga tahun terakhir serta menyelaraskan ke dalam aktvitas-aktivitas analisis value chain dan membuat kesimpulan dari hasil penelitian yang telah diteliti.

\section{HASIL PENELITIAN}

Aplikasi Analisis Value Chain

Mengidentifikasi Aktivitas Perusahaan ke dalam Aktivitas Value Chain

Tabel 1.

Aktivitas-Aktivitas Perusahaan

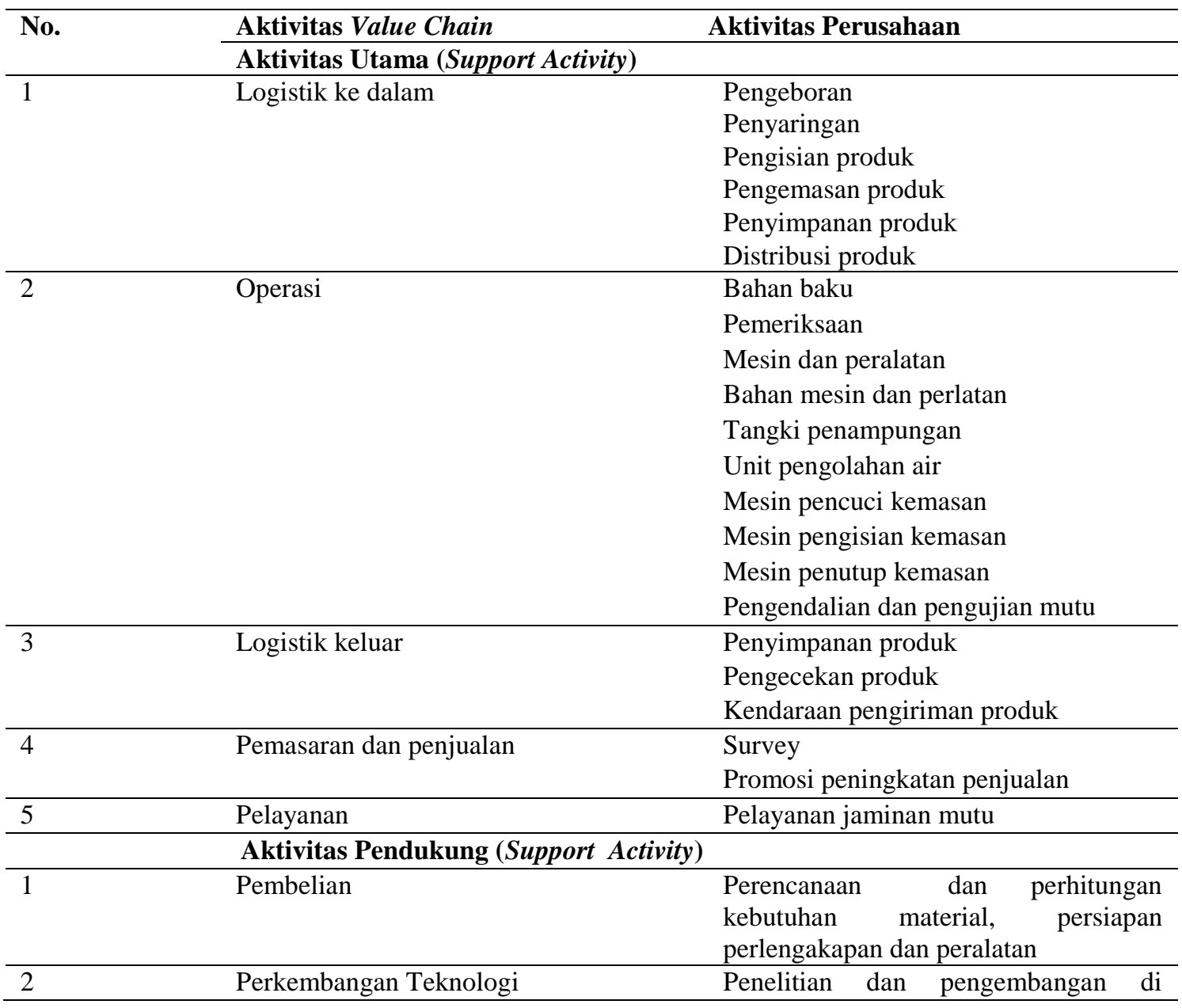




\begin{tabular}{lll}
\hline & & bidang operasi dan proses produksi \\
\hline 3 & Manajemen SDM & $\begin{array}{l}\text { Pemberian kompensasi dan pemakaian } \\
\text { karyawan }\end{array}$ \\
\hline 4 & Infrastruktur Perusahaan & $\begin{array}{l}\text { Perencanaan dan pemeliharaan } \\
\text { keperluan perusahaan }\end{array}$ \\
\hline
\end{tabular}

(Sumber : CV. Karunia Jaya data diolah)

\section{Mengidentifikasi Biaya dan Mendistribusikan pada Aktivitas Nilai}

Tahap ini dilakukan dengan mengidentifikasi biaya dengan cara menganalisis biaya dari laporan laba rugi yang didistribusikan ke dalam unit aktivitas value chain perusahaan. Pertama yaitu harga pokok produksi yang terdiri dari: a) beban listrik bahan baku, biaya ini digolongkan kedalam dua pada aktivitas nilai inbound logistick dan operations karena biaya ini digunakan untuk kebutuhan utama dalam proses produksi perusahaan; b) ongkos tukang, biaya ini digolongkan ke dalam aktivitas nilai outbound logistick, karena berkaitan langsung dengan perawatan peralatan perusahaan; c) biaya gaji, biaya ini digolongkan pada aktivitas nilai operations karena biaya ini berkaitan dengan kesejahteraan karyawan; d) biaya bahan bakar, biaya ini dikategorikan ke dalam dua aktivitas nilai yaitu outbound logistick dan firm infrastruktur.

Selanjutnya, e) biaya perlengkapan, biaya ini diaktergorikan ke dalam aktivitas nilai procurement karena biaya ini berhubungan dan menunjang aktivitas operations; f) biaya penyusutan, biaya ini digolongkan kedalam aktivitas nilai firm infrastruktur; g) ddministrasi dan pemasaran; h) bidang umum lainnya, biaya ini dikategorikan dalam aktivitas nilai technology development, karena pada biaya tersebut dapat mengembangkan terknologi dalam perusahan; i) biaya survey, biaya ini dikategorikan ke dalam aktivitas nilai marketing and sales, karena biaya tersebut dapat meningkatkan pemasaran produk; j) biaya perawatan, biaya ini digolongkan kedalam aktivitas nilai firm infrastruktur.

\section{Menentukan Keunggulan Kompetitif}

Usaha untuk mencapai nilai keunggulan yang kompetitif dapat dilakukan dengan cara mengurangi biaya. Berdasarkan pembahasan sebelumnya, diketahui bahwa salah satu nilai perusahaan yang memiliki nilai krisis adalah aktivitas nilai. Maka dari itu, perlu dilakukan tindakan berikut ini: 


\section{Menurunkan Biaya pada Aktivitas Nilai}

Menurunkan biaya pada logistik keluar yaitu operasi kendaraan pengiriman. Biaya transportasi mengalami peningkatan dengan total biaya transportasi sebesar Rp. 250.050.000. Biaya ini merupakan biaya dalam pengiriman barang ke suatu daerah, biaya tersebut perlu diminimalisir dengan menggunakan metode Actived Based Cost $(A B C)$ :

$$
\begin{aligned}
\text { ABC } & =\frac{\text { Total Biaya Transport }}{\text { Jarak Tempuh }(\mathrm{km})} \\
& =\frac{\text { Rp. } 250.050 .000}{18,4 \mathrm{~km}} \\
& =\text { Rp. } 13.589 .674
\end{aligned}
$$

Biaya ini diminimalisir menjadi Rp. 13.500.000. Jadi total biaya yang dapat diminimalisir adalah jumlah biaya yang dapat dikurangi dikali waktu transportasi. Biaya yang dapat dikurangi dikali jarak tempuh $(\mathrm{Rp} .89 .670 \times 18.4 \mathrm{~km}=\mathrm{Rp}$ 1.649.928.00).

Selanjutnya, menurunkan biaya pada aktivitas nilai pemasaran dan penjualan yaitu biaya promosi. Biaya promosi mengalami peningkatan dengan total biaya promosi sebesar Rp 5.450.000 biaya ini perlu diminimalisir dengan menggunakan metode Actived Based Cost (ABC):

$$
\begin{aligned}
\mathrm{ABC} & =\frac{\text { Total Biaya Promosi }}{\text { Jangka Waktu Promosi }} \\
& =\frac{\text { Rp. } 5.450 .000}{365} \\
& =\text { Rp. } 14.931
\end{aligned}
$$

Nominal ini merupakan biaya promosi dalam perhari. Biaya ini diminimalisir dengan cara mengurangi jumlah biaya promosi per hari menjadi Rp. 12.000. Jadi total biaya yang dapat diminimalisir adalah jumlah biaya yang dapat dikurangi dikali waktu promosi (Rp. 2.931 x $365=$ Rp. 1.069.815).

Tahap selanjutnya adalah menurunkan biaya pada aktivitas pembelian, yaitu pada biaya perlengkapan produk. Biaya perlengkapan produk mengalami peningkatan dengan total biaya perlengkapan sebesar Rp 350.000.000 biaya ini perlu diminimalisir dengan menggunakan metode Actived Based Cost (ABC): 


$$
\begin{aligned}
\text { ABC } & =\frac{\text { Total Biaya Perlengkapan Produk }}{\text { Jangka Waktu Pemakaian }} \\
& =\frac{\text { Rp. } 350.000 .000}{365} \\
& =\text { Rp. } 958.904,00
\end{aligned}
$$

Nlai ini merupakan biaya perlengkapan per hari. Biaya ini dapat diminimalisir dengan cara mengurangi jumlah biaya perlengkapan produk per hari menjadi Rp. 950.000. Jadi total biaya yang dapat diminimalisir adalah jumlah biaya yang dapat dikurangi dikali waktu pembelian $(\operatorname{Rp} 8.904$ x $365=\operatorname{Rp} 3.249 .960)$.

Berikut ini disajikan data pencapaian penurunan dan laporan laba rugi

\begin{tabular}{|c|c|c|c|c|}
\hline No & Aktivitas & Total Cost & $\begin{array}{l}\text { Analisis Value Chain } \\
\text { dengan Metode ABC }\end{array}$ & Cost Reduction \\
\hline 1 & Biaya Transport (Sales) & Rp 250.050.000 & Rp 1.649 .928 & $\begin{array}{ll}\text { Rp } & 248.400 .072\end{array}$ \\
\hline 2 & $\begin{array}{l}\text { Promosi Peningkatan } \\
\text { Penjualan }\end{array}$ & $\mathrm{Rp} \quad 5.450 .000$ & Rp 1.069 .815 & 4.380 .185 \\
\hline 3 & Perlengkapan & Rp 350.350 .000 & Rp 3.249.960 & Rp 347.100 .040 \\
\hline & Total & Rp 605.850.000 & Rp 5.969.703 & $\begin{array}{l}\text { Rp } \\
\end{array}$ \\
\hline
\end{tabular}
perusahaan sebelum dan sesudah menggunakan analisis value chain:

Tabel 2.

Data Pencapaian Penurunan Biaya

Berdasarkan data tabel 2, dapat dilihat bahwa setelah dilakukan analisis value chain, maka penurunan cost yang dapat dicapai adalah sebanyak Rp. 5.969.703 dari total cost awal.

\begin{tabular}{|c|c|c|c|c|}
\hline No & Uraian & $\begin{array}{c}\text { Tahun } 2018 \\
\text { Sebelum AVC }\end{array}$ & $\begin{array}{l}\text { AVC dengan } \\
\text { Metode ABC }\end{array}$ & Sesudah AVC \\
\hline \multirow[t]{8}{*}{1} & PENDAPATAN PERUSAHA & & & \\
\hline & $\begin{array}{l}\text { Penjualan Cup } 120 \mathrm{ml} \\
\text { (143.530 dus) }\end{array}$ & Rp. 1.650 .595 .000 & & Rp 1.650.595.000 \\
\hline & $\begin{array}{l}\text { Penjualan Cup } 220 \mathrm{ml} \\
(200.230 \text { dus })\end{array}$ & Rp. 2.362.714.000 & & Rp 2.362.714.000 \\
\hline & $\begin{array}{l}\text { Penjualan Cup } 220 \mathrm{ml} \text { (Bocor) } \\
\text { (530 dus) }\end{array}$ & 6.254 .000 & & 6.254 .000 \\
\hline & $\begin{array}{l}\text { Penjualan Botol } 600 \mathrm{ml} \\
\text { (52.325 dus) }\end{array}$ & Rp. 1.308 .125 .000 & & $\operatorname{Rp} 1.308 .125 .000$ \\
\hline & $\begin{array}{l}\text { Penjualan Botol } 1.500 \mathrm{ml} \\
\text { (9.595 dus) }\end{array}$ & $\begin{array}{ll}\text { Rp. } & 239.875 .000\end{array}$ & & $\mathrm{Rp} \quad 239.875 .000$ \\
\hline & Penjualan Galon (5.252) & 57.772 .000 & & 57.772 .000 \\
\hline & JUMLAH PENDAPATAN & Rp 5.625.335.000 & & Rp 5.625.335.000 \\
\hline 2 & BEBAN & & & \\
\hline
\end{tabular}

Tabel 3.

Laporan Laba Rugi CV. Karunia Jaya sesudah AVC CV. Karunia Jaya Per 31 Desember 2018 


\begin{tabular}{|c|c|c|c|c|c|}
\hline Biaya Perlengkapan Produksi & $\mathrm{Rp}$ & 350.000 .000 & Rp 3.249.960 & $\mathrm{Rp}$ & 347.100 .040 \\
\hline Gudang Penyimpanan & $\mathrm{Rp}$ & 8.550 .000 & & $\mathrm{Rp}$ & 8.550 .000 \\
\hline Biaya Listrik Operasional & $\mathrm{Rp}$ & 10.850 .000 & & $\mathrm{Rp}$ & 10.850 .000 \\
\hline Biaya Transport & $\mathrm{Rp}$ & 250.050 .000 & Rp 1.649.928 & $\mathrm{Rp}$ & 248.400 .072 \\
\hline Biaya Pemeriksaan & $\mathrm{Rp}$ & 1.950 .000 & & $\mathrm{Rp}$ & 1.950 .000 \\
\hline Biaya Survey & $\mathrm{Rp}$ & 1.500 .000 & & $\mathrm{Rp}$ & 1.500 .000 \\
\hline $\begin{array}{l}\text { Biaya Promosi Peningkatan } \\
\text { Penjualan }\end{array}$ & $\mathrm{Rp}$ & 5.450 .000 & Rp 1.069.815 & $\mathrm{Rp}$ & 4.380 .185 \\
\hline Biaya Perlengkapan Kantor & $\mathrm{Rp}$ & 8.500 .000 & & $\mathrm{Rp}$ & 8.500 .000 \\
\hline $\begin{array}{l}\text { Biaya Pemeliharaan Bangunan } \\
\text { Fasilitas }\end{array}$ & $\mathrm{Rp}$ & 8.554 .000 & & $\mathrm{Rp}$ & 8.554 .000 \\
\hline $\begin{array}{l}\text { Biaya Pemeliharaan Instalasi } \\
\text { Fasilitas }\end{array}$ & $\mathrm{Rp}$ & 1.875 .000 & & $\mathrm{Rp}$ & 1.875 .000 \\
\hline Biaya Administrasi Lainnya & $\mathrm{Rp}$ & 1.550 .000 & & $\mathrm{Rp}$ & 1.550 .000 \\
\hline JUMLAH BEBAN & $\mathbf{R p}$ & 648.829 .000 & & $\mathbf{R p}$ & 643.209.297 \\
\hline Laba Bersih & $\mathbf{R p}$ & 4.976 .506 .000 & & $\mathbf{R p}$ & .982 .125 .703 \\
\hline
\end{tabular}

\section{PEMBAHASAN}

CV. Karunia Jaya tidak menggunakan ketentuan biaya strategis dengan penganalisisan value chain, sehingga pihak manajer perusahaan tidak menyadari bahwasannya biaya-biaya yang dikeluarkan oleh perusahaan mengalami kenaikan. Dari kenaikan biaya akan mempengaruhi laba perusahaan, jika permintaan produk meningkat akan mendapatkan keuntungan yang lebih besar tetapi jika permintaan hanya berjumlah sedikit dan biaya yang dikeluarkan banyak maka laba perusahaan akan turun atau berjumlah kecil.

Berdasarkan laporan keuangan jumlah laba bersih pada CV. Karunia Jaya dalam tiga tahun terakhir mengalami penurunan antara tahun 2016-2018. Jumlah laba bersih pada tahun 2016 perusahaan memperoleh Rp. 618.511.945, tahun 2017 sebesar Rp. 659.610.73. Sedangkan tahun 2018 sebesar Rp. 425.667.600. Jumlah laba bersih pada perusahaan mengalami penurunan dikarenakan biaya-biaya yang dikeluarkan setiap tahunnya mengalami kenaikan. Biaya-biaya yang mengalami kenaikan diantaranya yaitu biaya transport (sales), biaya survei, promosi peningkatan penjualan, bidang pengembangan produk, biaya perlengakapan produksi, biaya lain-lain, ongkos penurunan bahan baku, adminitrasi transfer, operasional ambil galon, fee galon, operasional menaikkan mesin dan perbaikan forsclift.

Perusahaan mengalami kenaikan pada tahun 2017 dengan jumlah laba bersih sebesar Rp 659.610.731 dengan jumlah pendapatan sebesar Rp 1.781.779.531 dikurangi dengan beban perusahaan sebesar Rp 1.122.168.800. Dilihat dari jumlah beban yang dikeluarkan oleh perusahaan mengalami kenaikan pada tahun 2017 sebesar 5,7\%. 
Sedangkan pada tahun 2018 jumlah laba bersih perusahaan adalah 425.667.600. Dari jumlah laba bersih tersebut, perusahaan mengalami penurunan sebesar $35.4 \%$ atau sebesar Rp 233.943.131. Penyebab dari penurunan laba bersih dikarenakan jumlah beban perusahaan mengalami kenaikan, sehingga dapat mempengaruhi jumlah laba bersih pada perusahaan. Selain beban perusahaan naik, karena jumlah permintaan konsumen berkurang atau pesanan dari produk rendah sehingga jumlah persediaan produk tinggi. Dari pembahasan di atas, penentuan biaya strategis melalui analisis value chain sangatlah penting agar manajer mengetahui peningakatan atau penurunan biaya yang dikeluarkan dan dapat mengontrol segala aktivitas pada CV. Karunia Jaya.

Menurut Widodo (2008), pengendalian biaya dapat dilakukan dengan mengeliminasi aktivitas yang tidak memberikan nilai tambah sebagai upaya dalam mengendalikan biaya secara efesien. Analisis value chain dapat diterapkan untuk mencapai strategi cost leadership. Hal ini dikarenakan analisis tersebut memandang perusahaan sebagai rangkaian aktivitas yang saling berkaitan. Pengendalian biaya juga bisa dicapai dengan cara meningkatkan koordinasi dan melaksanakan aktivitas dengan lebih optimal. Jika perusahaan dapat mengendalikan biaya secara baik dan selalu mencari cara agar perusahaan berpeluang untuk mencapai cost leadership sehingga upaya dalam mengendalikan biaya dapat tercapai dan berjalan dengan efisien.

Menurut Periansya (2011) analisis value chain dapat memberikan gambaran mengenai posisi perusahaan dalam rantai nilai industri. Analisis ini juga dapat membantu perusahaan untuk memahami rantai nilai yang membentuk produk tersebut sehingga dapat digunakan untuk memahami posisi perubahan dalam suatu rantai yang membentuk nilai suatu produk. Hal ini sangat penting untuk dilakukan agar dapat mengidentifikasi kesempatan dalam persaingan. Dengan adanya penerapan value chain, perusahaan juga dapat menentukan strategi yang akan dipakai dalam persaingan sehingga pihak manajemen dapat menentukan strategi untuk meningkatkan daya saing produk. 


\section{SIMPULAN}

Hasil penelitian menunjukkan bahwa dalam menentukan biaya strategis, perusahaan tidak melihat biaya strategi melalui analisis value chain sehingga menyebabkan manajer tidak mengetahui jika biaya yang dikeluarkan oleh perusahaan mengalami kenaikan. Maka dari itu, pengaplikasian analisis value chain sangat diperlukan bagi CV. Karunia Jaya untuk mengidentifikasi biaya yang tidak bernilai tambah, sehingga bisa meningkatkan keunggulan kompetitif bagi CV. Karunia Jaya. Untuk mencapai nilai keunggulan yang kompetitif, dapat dilakukan dengan cara mengurangi biaya pada aktivitas nilai dan membantu manajemen dalam membuat keputusan strategis dengan mengetahui aktivitas-aktivitas mana yang memberikan nilai tambah dan yang tidak memberikan nilai tambah.

\section{DAFTAR PUSTAKA}

Arikunto, S. (2006). Metodelogi Penelitian. Yogyakarta: Bina Aksara

Blocher, E., Chen, C., \& Lin, L. (2007). Manajemen Biaya, Edisi 3. Jakarta: Salemba Empat

Blocher, E., Stout, D., Juras, P., \& Cokins, G. (2016). Cost Management: A Strategic Emphasis, 7 Edition. New York: Mc Graw Hill

Daljono, D. (2011). Akuntansi Biaya Penentuan Harga Pokok dan Pengendalian, Edisi Ketiga. Semarang: Badan Penerbit Universitas Diponegoro

Hongren, C. T. (2009). Pengantar Akuntansi Manajemen, Edisi 7. Jakarta: Erlangga

Magretta, J. (2014). Understanding Michael Porter: Panduan Paling Penting tentang Kompetisi dan Strategi. Yogyakarta: Andi

Mulyana, D. (2011). Komunikasi Lintas Budaya. Bandung: Rosda Karya

Mursyidi, M. (2010). Akuntansi Dasar. Bogor: Ghalia Indonesia

Periansya, P. (2011). Penerapan Analisis Value Chain sebagai Strategi Manajemen Biaya untuk Keunggulan Kompetitif. Teknika, 31(1), 56-60

Porter, M. E. (1994). Keunggulan Bersaing. Jakarta: Binapura Aksara

Steiner, G. A., \& Miner, J. B. (1997). Kebijakan dan Strategi Manajemen, Edisi Kedua. Jakarta: PT. Gelora Pratama

Sudjana, S. (2006). Metode Statistik. Jakarta: Rineka Cipta

Widodo, H. (2008). Analisis Value Chain guna Mencapai Strategi Cost Leadership dalam Meningkatkan Efesiensi Biaya (Studi pada Perusahaan "X" di Sidoarjo). Jurnal Bisnis dan Manajemen, 1(1), 38-49

Wijaya, S. R. (2012). Analisis Penentuan Harga Pokok Produksi pada PT. Bangun Tenera Riau Pekanbaru. Jurnal Ekonomi STIE Haji Agus Salim Bukittinggi, 12(2), 104-114

Witjaksono, A. (2006). Akuntansi Biaya, Cetakan Pertama. Yogyakarta: Graha Ilmu 